症例

広汎な皮下気腫像を呈した Fournier's gangrene の 1 例

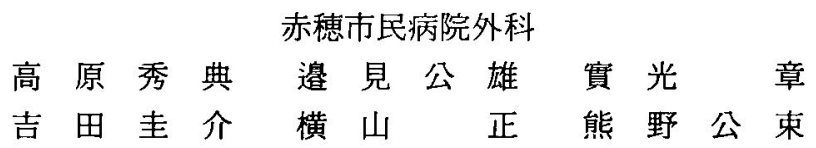

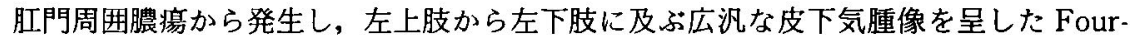
nier's gangrene の 1 例を経験したので若干の文献的考察を加えて報告する.症例は51歳 男性で肛門周囲および陰亳の疼痛, 腫脹, 発赤を主訴に来院した. 炎症反応が著明で, 頸部から左下肢まで握雪感を認め, CT 検査にて左上肢から左下肢まで連続して皮下気 腫像を認めた。即日，緊急手術を行い，肛門周囲および陰鸾の壊死組織を除去するとと もに胸壁から下部腹壁まで切開, ドレナージを行った。術後 8 日目に炎症範囲の㹡大が 認められたため, 切開, 排膿術を追加した。

本症は重篤な経過をとることが多いため, 膿瘍部分の切開, 排膿と壊死組織の除去を 含む早期の適切な治療および創部污染の回避や全身管理が必要であると思われた。

索引用語：Fournier's gangrene, 壊疽性筋膜炎, 肛門周囲膿瘍

\section{緒言}

Fournier's gangrene は陰襄や会陰部に急激に発症 する壊死性蜂窩織炎で重篤な感染症の一つである。最 近われわれは, 左上肢および頸部から左大腿部まで連 続して皮下気腫像を認めた Fournier's gangrene の 1 例を経験したので若干の文献的考察を加えて報告す る.

$$
\text { 症例 }
$$

患者：51歳，男性。

主訴：肛門周囲および陰襄の発赤, 腫脹, 疼痛.

既往歴：数年前から糖尿病.

家族歴：特記すべきことなし.

現病歴: 平成 8 年 8 月 7 日より肛門周囲の疼痛を自 覚し, 8 月10日より陰襄の発赤, 腫脹, 疼痛が加わつ た。体温も $39^{\circ} \mathrm{C}$ 上昇し， 8 月11日には坐位が不可能 となったため, 当院緊急外来を受診し, 同日入院した.

入院時現症：体温 $39.2^{\circ} \mathrm{C}$, 血圧 $110 / 65 \mathrm{mmHg}$. 肛門 周囲から陰桽にかけて著明な発赤, 腫脹を認めた（図 1)。また，頸部から左大腿部まで連続して握雪感を認 めた.

入院時血液検査 : 白血球数 $23,800 / \mathrm{mm}^{3}, \mathrm{CRP} 26.54$ $\mathrm{mg} / \mathrm{dl}$ と増加し, 著明な炎症所見を認めた。また, 血

1997年 5 月 8 日受付 1997 年 9 月 5 日採用
糖値は $410 \mathrm{mg} / \mathrm{dl}$ と高值を呈していた（表 1 ).

胸腹部単純 $\mathrm{X}$ 線写真：胸部単純 $\mathrm{X}$ 線写真では頸部 から左胸壁にかけて皮下にガス像を認め, 下腹部単純 $\mathrm{X}$ 線写真では陰龔, 左大腿部を中心に大小のガス像を 認めた（図 2 )。

CT 検査: 頸部, 左上腕, 胸壁, 腹壁, 陰賈および左 大腿部の皮下や筋層内に大小のガス像を認めた(図 3， 4 ).

以上より, 肛門周囲膿場から発生し, 頸部, 左上腕 から左大腿部まで炎症が波及した Fournier's gan-

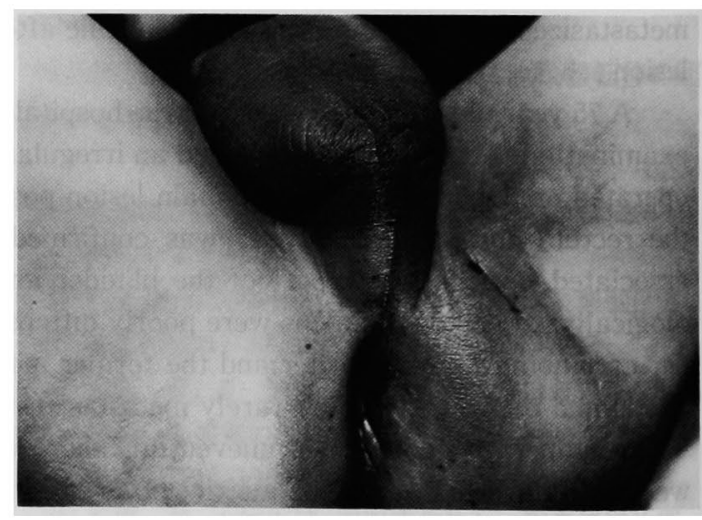

図 1 入院時の会陰部所見 : 肛門周囲から陰衰にかけ て著明な発赤, 腫脹を認めた。 
grene と診断し, 即日, 全身麻酔下に緊急手術を行っ た。

手術所見：肛門周囲および陰虽を切開すると多量の 膿汁が流出した。同部を広範囲に切開し，壊死組織の 除去㧍よび洗浄を行い, ペンローズドレーンを留置し た、胸壁および腹壁は㩧雪感の強い部位を数力所大き く切開したが，膿汁の流出は認められなかった。陰軎 および肛門周囲の膿汁を提出したところ好気性培養よ り E. coli が検出され，嫌気性培養では菌は証明されな かった.

組織学的所見：切除した肛門周囲組織の病理組織学 的所見では，ガス貯留による空胞様変化が存在し，著 明な好中球浸潤および組織壊死を認めた（図 5 )。

術後経過：緊急手術後より抗生物質は IPM/CSを $2.0 \mathrm{~g} / \mathrm{day}$ ，また，DIC 対策としてメシル酸ナファモス タットを $200 \mathrm{mg} / \mathrm{day}$ 投与し, 絶食, IVH 管理とし,イ

\section{表 1 入院時血液検查所見}

\begin{tabular}{lc|lc}
\hline WBC & $23,800 / \mathrm{mm}^{3}$ & $\mathrm{UN}$ & $24 \mathrm{mg} / \mathrm{dl}$ \\
$\mathrm{Ht}$ & $46.9 \%$ & $\mathrm{Cre}$ & $1.2 \mathrm{mg} / \mathrm{dl}$ \\
Plts & $260,000 / \mathrm{mm}^{3}$ & $\mathrm{CRP}$ & $26.54 \mathrm{mg} / \mathrm{dl}$ \\
T. Bil & $3.6 \mathrm{mg} / \mathrm{dl}$ & $\mathrm{pH}$ & 7.49 \\
$\mathrm{GOT}$ & $17 \mathrm{IU} / \mathrm{L}$ & $\mathrm{PaO}_{2}$ & $88.9 \mathrm{mmHg}$ \\
GPT & $39 \mathrm{IU} / \mathrm{L}$ & $\mathrm{PaCO}_{2}$ & $31.0 \mathrm{mmHg}$ \\
LDH & $529 \mathrm{IU} / \mathrm{L}$ & $\mathrm{BE}$ & $2.5 \mathrm{mmol} / \mathrm{L}$ \\
$\mathrm{CPK}$ & $177 \mathrm{IU} / \mathrm{L}$ & $\mathrm{HbAlc}$ & $7.7 \%$ \\
$\mathrm{BS}$ & $410 \mathrm{mg} / \mathrm{dl}$ & & \\
\hline
\end{tabular}

ンスリンを用いて糖尿病管理も行った。また，局所の 洗浄を繰り返し行ったが, 陰隻および肛門周囲の壊死 部分が拡大し，膿汁の流出が続くため(図 6)，第 8 病 日に全身麻酔下に壊死組織の切除およびドレナージを 追加した。

第 2 回手術後より抗生物質は CAZ $2 \mathrm{~g} / \mathrm{day}$, CLDM $1,200 \mathrm{mg} / \mathrm{day}$ を用い, 前回と同様に絶食, IVH 管理と して，便汁による創部の污染を極力避けることを続け た. 次第に体温, 白血球数, CRP 値が正常化し, 臨床 症状および局所所見も改善してきたため，第20病日よ り経口攝取を開始した(図7)。その後, 経過は良好で 陰垔の創部は治癒し，肛門周囲の肉芽も良好となった ため，第50病日に軽快退院した（図 8).

\section{考察}

Fournier's gangrene は, 会陰部および外性器に発症 する重症壊疽性筋膜炎で，1884年に Fournier'が若い 健康男子の外性器に発症した電撃的壊疽を報告して以 来, 欧米では500例近くの報告がある2). Fournier は自 然発症した症例を報告しているか゚，現在では本症は会 陰部周囲の外傷や尿道周囲の炎症および肛門周囲の感 染などが原因と考えられている゙!。

陰虂周囲に急激な壊疽性蜂窩織炎が生じやすい理由 として，陰雃部は汗腺に富み，皮下組織が層状構造を なし，血行が比較的乏しいため，一旦，皮下感染が生 じると細菌の増殖が容易であるためと考えられてい

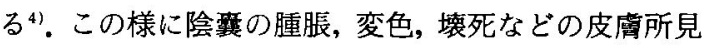
が著明であれば電撃的な発症でも診断はつきやすい
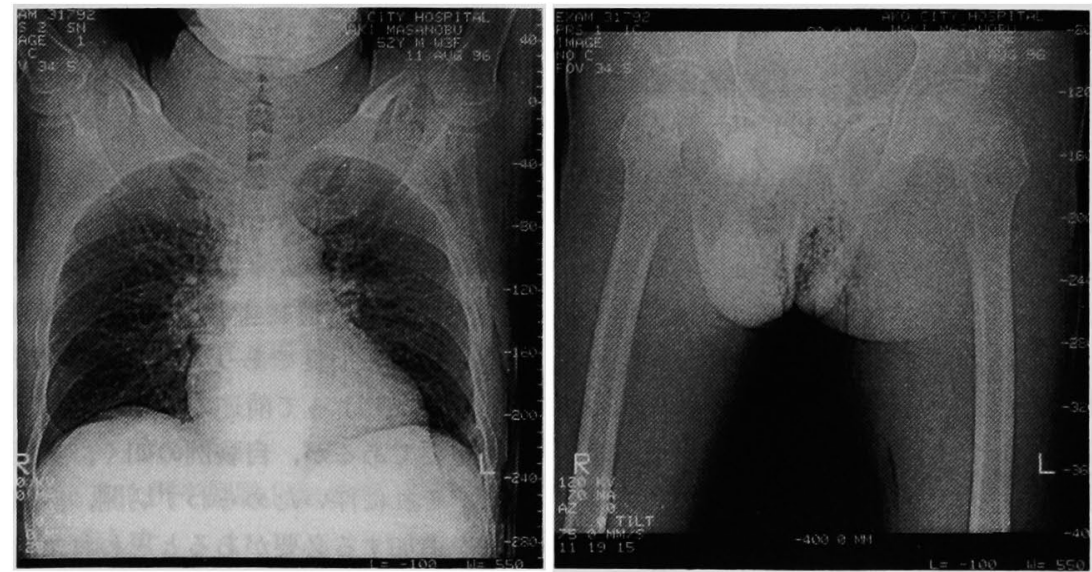

図 2 胸, 腹部単純 $\mathbf{X}$ 線写真 : 胸部単純 X 線写真では頸部から左胸壁にかけて皮下 にガス像を認めた。下腹部単純 X 線写真では陰覇, 左大腿部を中心に大小のガス像 を認めた。 


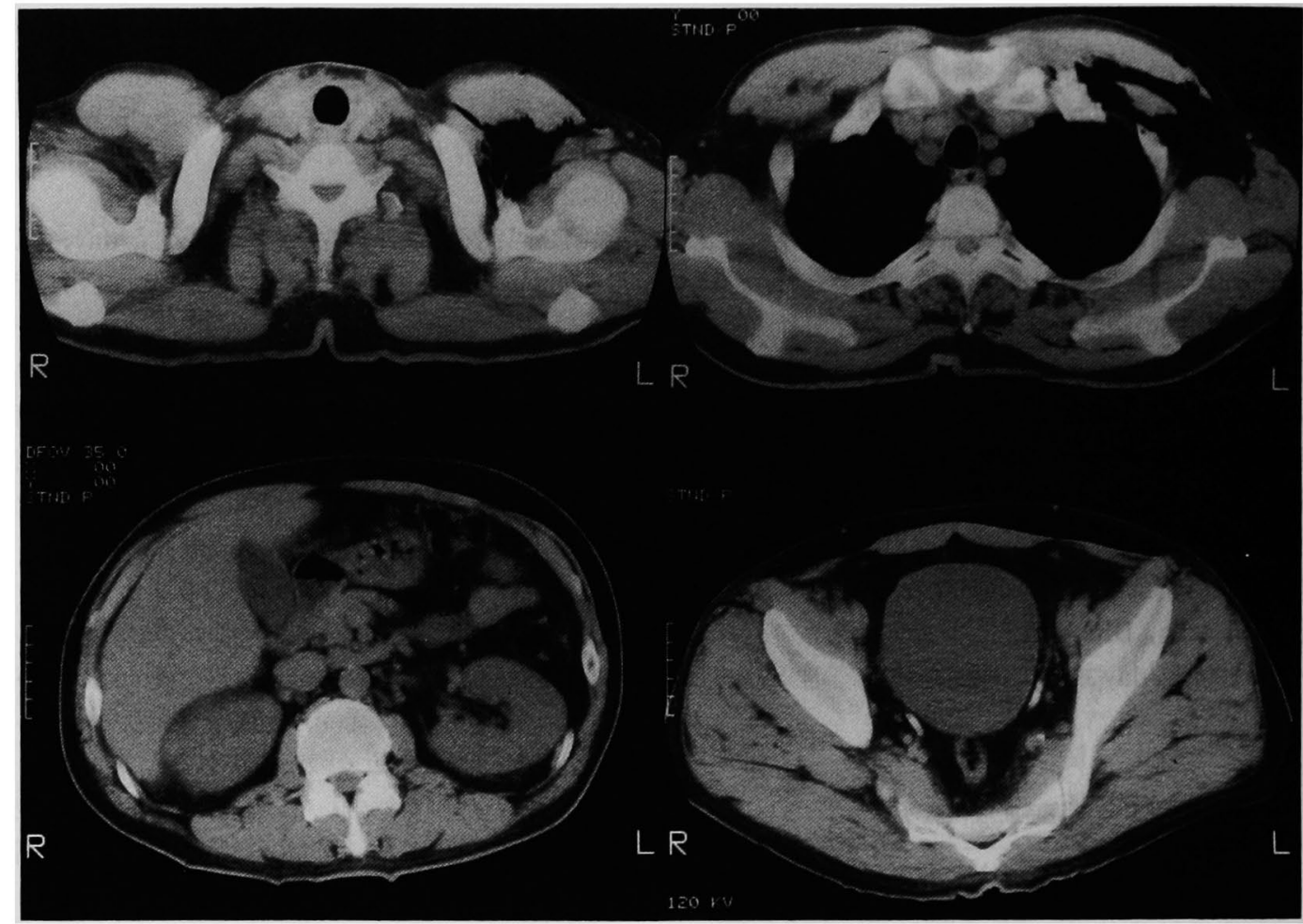

図 3 頸部一胸部 CT：頸部，左上腕および胸壁の皮下にガス像を認めた。

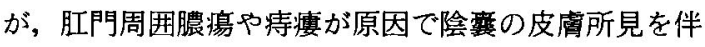
わず，恥骨後面や骨盤直腸窝を経由して下腹部の preperitoneal space に進展していく様式もあり ${ }^{5 / 6)}$ ，この 場合は診断が遅れがちとなり重篤化をきたしやすい.

本症の多くは陰嘦や会陰部に炎症が限局している が, 自験例では左上腕, 頸部から胸壁, 腹壁, 陰襄, 左大腿部までガス像が連続しており，この様に拡大し た炎症所見を呈する報告例は稀であると思われる。

起因菌では, Bacteroides などの熑気性菌と Escherichia coli やStreptococcus などの好気性菌との混合 感染が本邦では多いが》, Clostridium 感染によるガス 壊疽の報告もある2). 自験例では E. coli の単独感染で あった．検索しえた範囲内ではこの報告例はなかっ

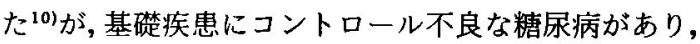
そのため微小血管障害，好中球機能の低下，免疫機能 の低下，脱水および全身の糖の利用障害などのため易 感染性の状態で肛門周囲膿瘍より本疾患が発症し急激 に全身に拡がり，ガス貯留が広範囲に認められたと考 えられる。

治療は早期に切開，排膿し，徹底した壊死組織の除
去および洗浄を行うことが重要であり ${ }^{87}$, 感受性に応 じた抗生物質の選択も重要である ${ }^{9 !}$.また, 肛門部の污 染を避けるために diverting colostomy を造設するこ とが以前より有用とされてきたが, 自験例の如く, 腹 壁に炎症の波及が認められる例では colostomy の造 設は避けるべきであり，また，IVH や低残渣食による 栄養管理とコデインなどを用いた便通調節を行えば， colostomy は不必要であるとの報告もある11!。

本疾患は, 自験例の如く短期間に炎症が広範囲に波 及しやすく, endotoxin shockなどに陥り重篤な経過 をたどりやすい，本疾患の予後は，全身管理の向上や 抗生物質の発達により改善したとはいえ，死亡率は 12 45\%と不良であり7，処置が遅れると死亡率が高 くなる ${ }^{12}$. よって前述の早期の診断と適切な治療が最 も重要であるが, 自験例の如く, 炎症範囲が拡大すれ ば，それに伴いためらわず切開，排膿，壊死組織の除 去を追加する必要があると思われた。

\section{結 語}

肛門周囲膿瘍から発症し，会陰部をはじめ，上腕か ら大棴部までの広範囲におよぶ蜂窩織炎をきたした 


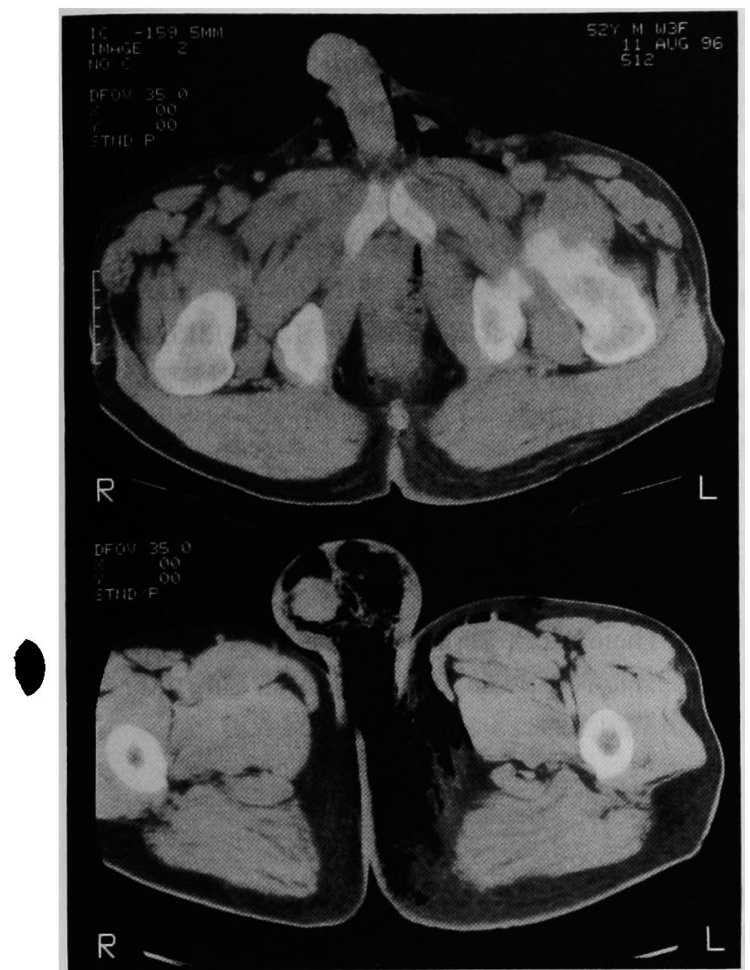

図4 下腹部 CT：腹壁，陰襄および左大腿部の皮下 や筋層内に大小のガス像を認めた。

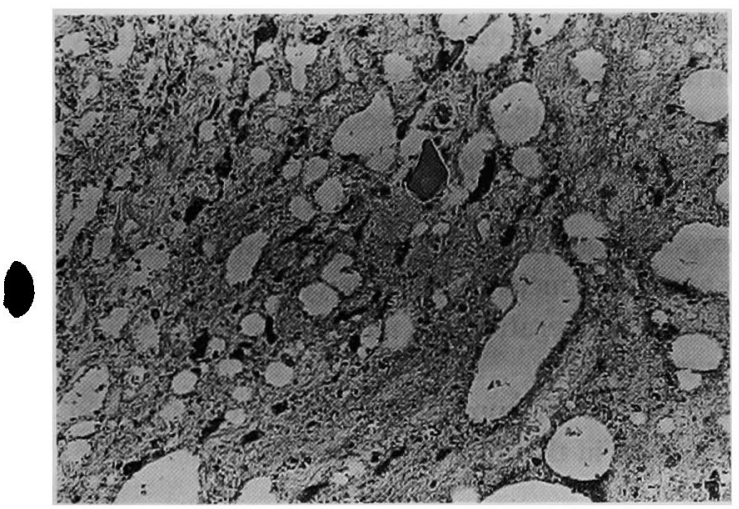

図 5 病理組織学的所見：肛門周囲組織には,ガス貯 留による空胞様変化が存在し, 著明な好中球の浸潤 および組織壊死を認めた。

Fournier's gangrene の 1 例を経験したので, 若干の文 献的考察を加えて報告した。

\section{文 献}

1) Fournier FA: Etude clinique de la gangrene foudroyante de la verge. Semaine Med 4:69-

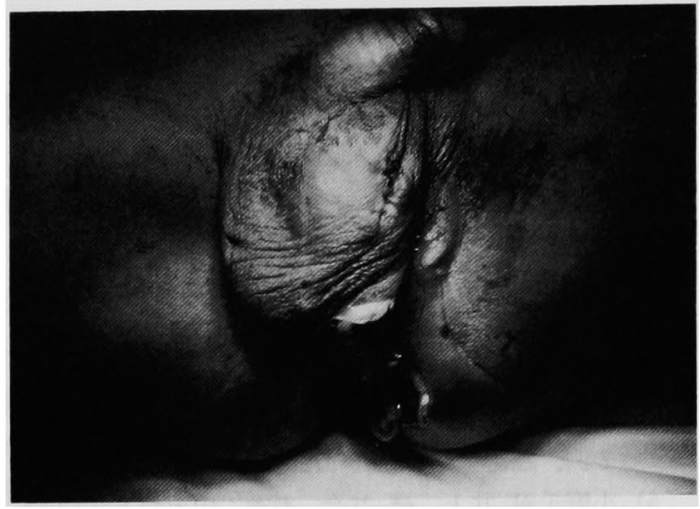

図 6 術後 8 日目の会陰部：術後 8 日目には陰变およ び肛門周囲の壊死部分が应大し, 膿汁の流出が続い た.

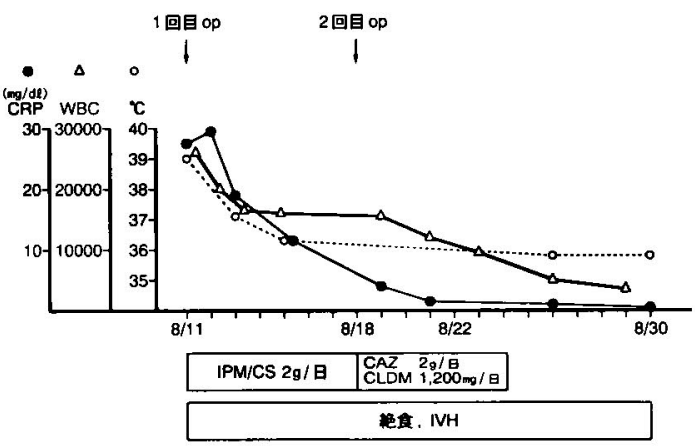

図 7 術後経過: 追加切除を行った後, 臨床症状, 検 查值とも軽快に向かった。

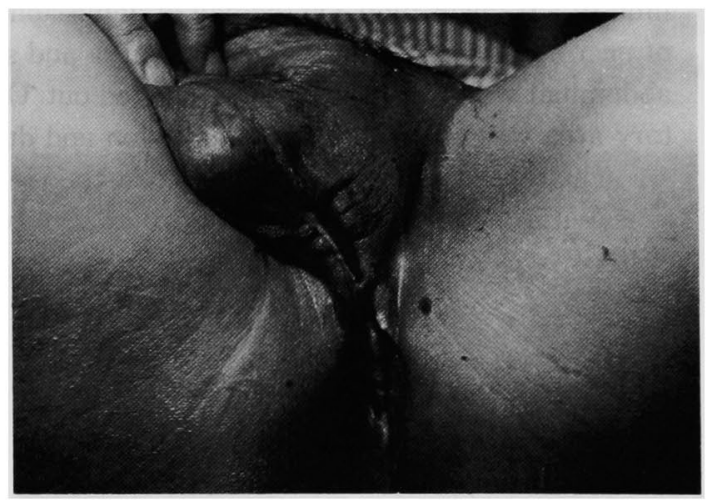

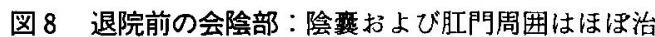
瘾した。 
70,1884

2）若杉純一, 金 正文, 筑田康一郎他：痔瘦加ら発生 したガス産生性壤痽性筋膜炎 (Fournier's gangrene)の 1 例. 日本大腸肛門病会誌 $45 ： 480-$ 484, 1992

3) Jones RB, Hirschmann JV, Brown GS, et al : Fournier's syndrome: Necrotizing subctaneous infection of male genitalia. J Urol 122 : 279282,1979

4）篠島弘和, 榊原尚行, 藤田信司他：フルニエ壊瘨の 2 例. 臨泌 $48: 970-972,1994$

5）小野千尋, 井上 豪, 井合 哲他：内攻型 Fournier 症候群の 1 例. 日臨外医会誌 57：2041－2044, 1996

6）丹羽篤朗, 佐々木信義, 三井敬盛他：痔瘦加ら骨盤 直腸窩, 後腹膜腔, 腹壁へ広範に広がった壊死性筋 膜炎の1例. 日消外会誌 $26: 2883-2887,1993$

7）児島康行, 井上彦八郎, 藤原祥子他：糖尿病に合併
した Fournier's gangrene の 1 例. 泌外 6:1133 $-1136,1993$

8）草川雅之, 五嶋博道, 山碕芳生他：Fournier 壊疽 の臨床像を呈した重症 Synergistic Necrotizing Cellulitis $の 1$ 救命例. 臨外 $43: 269-273,1988$

9）水野 章, 桜井 敏, 保里恵一他：外科領域におけ る重症壊死性筋膜炎一-特に Fournier's gangrene について一。化療の領域 $5: 1307-1315,1989$

10）石井 寛, 成澤 寛, 幸田 弘：壊死性筋膜炎 10例 の統計的観察一 I 型と II 型の比較. 臨皮 50:18 $-20,1996$

11) Chris S, Frank JH, Philip BD: Necrotizing infections of the perineum. Southern Med J 86 : $908-911,1993$

12) Thomas LB, Vernon JH, Claude HO: Necrotizing soft-tissue infections. Arch Surg 131:846 $-854,1996$

\title{
A CASE OF FOURNIER'S GANGRENE WITH WIDE-RANGING SUBCUTANEOUS EMPHYSEMA
}

\author{
Hidenori TAKAHARA, Kimio HENMI, Akira JIKKO, Keisuke YOSHIDA, \\ Tadashi YOKOYAMA and Kimitsuka KUMANO \\ Department of Surgery, Ako City Hospital
}

A case of Fournier's gangrene with wide-ranging subcutaneous emphysema which continuously extended from the left upper to left lower limbs is reported, together with a review of the literature.

A 51-year-old man was seen at the hospital because of pain, swelling, and reddening of the scrotum and perineum. Inflammatory reaction was remarkable and crepitant sensation was confirmed from the neck to left lower limb. CT revealed continuous subcutaneous emphysema covering from the left upper limb to left lower limb. On the day of admission, an emergency operation was conducted, when removal of necrosed tissues from the perianal area and scrotum as well as incision from the chest wall to lower abdominal wall and drainage was carried out. On the eighth postoperative day an increase in inflammatory area was confirmed, and so incision and drainage were added.

This disease often has a fatal course. We need to provide an appropriate early treatment and repeated incision with drainage in accordance with an increase in the inflammatory area. 